\title{
A perfect storm: Violence toward women in the Bakken oil patch
}

\author{
Rick Ruddell \\ Professor \\ Justice Studies \\ University of Regina \\ CANADA \\ Sarah Britto \\ Assistant Professor \\ Criminal Justice Administration \\ California State University, Dominguez Hills \\ UNITED STATES OF AMERICA
}

Contact author - Rick Ruddell; rick.ruddell@uregina.ca

\begin{abstract}
Communities in the Bakken region of Montana and North Dakota that experienced a resourcebased boom starting in the mid-2000s had significant increases in the volume and seriousness of violence toward women. We identify five community factors distinctive to these boomtowns that created a perfect storm where these crimes proliferated including: (a) precarious housing arrangements; (b) the social isolation of women; (c) lack of domestic violence shelters and other social supports for survivors; (d) a workplace culture in the oilfields supportive of substance abuse and hyper-masculinity, and; (e) the inability of boomtown justice systems to respond to these crimes in an effective or timely manner. Although this critical analysis describes the outcomes in a U.S. jurisdiction, the conditions in rapid growth communities are similar throughout the globe and we suggest these community factors be considered in the responses to domestic and intimate partner violence in these rural areas. Our goal in identifying these factors is to work toward the development of an intervention model for officials anticipating resourcebased booms to mitigate this violence.
\end{abstract}

Keywords: boomtown crime, violence toward women, resource extraction, intimate partner violence. 


\section{Introduction}

Research dating back to the 1970s reveals that antisocial behavior, disorder, and crime increases in sparsely populated rural counties impacted by the rapid population and industrialization of natural resource-based booms were commonplace (Freudenburg \& Jones, 1991). The issue of boomtown crime, or the boom-crime relationship, has been the subject of numerous studies since the introduction of hydraulic fracturing (fracking) led to a significant expansion in the number of oil and natural gas wells being drilled in rural America after 2005 (see Ruddell, 2017 for a summary of those studies). Rapid population growth placed significant demands on the health, education, and social service agencies in these communities as local government officials struggled to manage the influx of workers and their families (Flanagan et al., 2014; Jacquet, 2014; Jacquet et al., 2018; Weber et al., 2014). Workers in these agencies responded to increases in substance abuse and physical and mental health-related problems, a lack of safe and affordable housing, overtaxed social, educational and health-care systems due to inadequate local infrastructure, a distorted sex ratio where men outnumbered women, and a decreased quality of life due to air, water, and noise pollution, overcrowding, rapid population turnover, and traffic collisions and congestion.

Scholars have labeled the negative outcomes of these resource-based booms as social ills or boomtown effects (Government of New Brunswick, 2012; Thomas et al., 2016). And although our study focuses on what occurred in the United States (U.S.), researchers have identified a similar set of social ills when these booms occur in out-of-the-way places in Australia, Canada, and the United Kingdom (Britto, 2016; Keough, 2015; Ruddell \& Ortiz, 2015; Sincovich et al., 2018; Streteskya et al., 2018).

We identify five factors from the extant literature and ongoing research that we propose place women at higher risk for victimization in boomtown communities. In what follows we briefly describe the boom-crime relationship as well as the contextual elements leading to the formation of these gender stratified conditions, describe these five factors, and discuss how understanding this array of related risks can help community leaders and stakeholders develop interventions to reduce violence toward women in places undergoing resource-based booms. Although our focus is on what is happening in the U.S., Adamson (2017) observes that the violence toward women occurring in the Bakken is consistent with extraction activities across the globe (see also Deer \& Nagel, 2017; Map Room, 2017).

\section{The boom-crime relationship}

Most boomtown scholarship since 2005 reports that increases in crime are associated with the types of public order offenses involving large numbers of young men abusing alcohol and drugs, such as assaults, disorderly conduct, and impaired driving (Lim, 2018; Montana All Threat Intelligence Center, Montana Board of Crime Control, 2014; North Dakota State and Local Intelligence Centre, 2012). In terms of crimes against persons, the number of assault cases processed by North Dakota courts grew by over four-fifths (82\%) between 2002 and 2014 while the population grew by less than one-fifth (Ruddell, 2017). The increased number of assaults was associated with a $61 \%$ rise in the homicide rate using a three-year average of 2006 and 2008 when the oil boom started - and the three-year average of 2017 to 2019 (Attorney General of 
North Dakota, 2020). Almost one-half (45\%) of the murders occurring between 2000 and 2019 were classified as domestic violence offenses (Attorney General of North Dakota, 2020).

There was a similar pattern in Montana, and the Montana Board of Crime Control (2019) reports the number of homicides increased by $88 \%$ between January 1, 2007, and December 2017. Of those offenses, the Montana Department of Justice (2019) found that the intimate partner homicides represented 43\% of all deliberate and non-negligent homicides between 2011 and 2018. Even with those increases, the Montana and North Dakota homicide rates were about one-half the national average (Federal Bureau of Investigation, 2019). Like most jurisdictions, most crimes occurring in the Bakken boomtowns are misdemeanors and the sheer volume of these offenses has placed considerable demands on law enforcement agencies (Archbold et al., 2014; Dahle \& Archbold, 2015).

There is less research focusing on violence toward women. In the 1970s and 1980s era scholarship on boomtown crime, Moen (1981) documented the presence of workplace harassment in these places, and Endo et al. (1984) identified the correlates of family violence in these boomtowns. Studies carried out in the Bakken since the 2007 boom reveal that women are fearful of being victimized (Mrozla et al., 2018; Pippert \& Zimmer Schneider, 2018). Kilanski's (2015) fieldwork in a U.S. boomtown reveals that media accounts and community gossip contribute to a fear of victimization and how these fears shaped women's choices about where they travel, shop, or work. O'Connor's (2015) study of a Canadian boomtown found that women were more fearful of victimization than men after the population increased and their fear reflects crime statistics that showed elevated levels of violence against women in these boomtowns.

With respect to specific studies about violence toward women in the Bakken, a survey of law enforcement officers found that over four-fifths of North Dakota agencies had experienced an increase in domestic violence and sexual assault incidents after the start of the oil boom (Dooley \& Ruzinka, 2013). Jayasundara, Heitkamp, et al.'s (2016) study reveals that incidents of domestic and dating violence, sexual assault, and stalking increased in oil-impacted counties throughout the Bakken region. Martin et al. (2019) compared rates of domestic violence in the Bakken and non-Bakken regions between 2006 and 2012. They found that in the oil-impacted or boom counties, the rates of family violence and intimate partner violence increased by $26.7 \%$ and $22.8 \%$ respectively. When it came to acts of serious violence-murder, non-negligent manslaughter, rape, aggravated assault, and robbery-Martin et al. (2019) found that family violence increased by $47.1 \%$ while intimate partner violence rose by $59.2 \%$.

This increase in offenses was not, however, uniformly distributed and some oil-impacted counties had much higher rates of police reported crimes than others (O'Connor, 2017). The finding of increased sexual assaults of women after the start of a resource-based boom has also been reported by scholars examining the boom-crime relationship in a large sample of U.S. oilimpacted counties (James \& Smith, 2017) and Komarek's (2018) study of natural gas production in the Marcelles Shale region in the Appalachian region in the eastern U.S. 


\section{Violence toward women in resource-based boomtowns}

Before describing the five factors thought to contribute to the increased violence toward women, it is important to place our analyses in context. First, the Bakken region encompasses an area of about 200,000 square miles straddling the Canadian and U.S. border, although most resource extraction occurs in western North Dakota and eastern Montana. This region has undergone three oil booms; in the 1950s, 1980s, and after 2005. Oil production in the last boom peaked in 2015 after a global decline in commodity prices, but daily production has rebounded and exceeded the 2015 peak by December 2019 (U.S. Energy Information Administration, 2020a).

The volume and seriousness of crime in resource-based communities are associated with the location, magnitude, and duration of specific booms. The oil and gas boom occurring in the Marcelles Shale region after 2005, for example, was spread over a large region, and that minimized the impacts of population growth. That contrasts with what happened in the Bakken, where the boomtown effects were concentrated in a small number of counties (Jayasundara, Heitkamp, et al., 2016; Martin et al., 2019; O’Connor, 2017). Moreover, some booms are of short duration and may only disrupt a community for a year or two - such as the construction phase of a mine that requires a large workforce - while oil booms in some places occur in cycles of boom and bust spanning decades. The magnitude of booms also differs, and high commodity prices can intensify levels of community disruption. In 2017, for instance, North Dakota's governor challenged the oil industry to double that state's production from one to two million barrels of oil per day (Springer, 2018). Doubling production will increase the workforce required to extract these resources and these newcomers will place additional demands on a community's public safety organizations, health, education, and social service agencies and all non-profit service organizations.

Our analysis about the factors contributing to high rates of domestic and intimate partner violence in resource-based boomtowns is based on our ongoing qualitative and quantitative research on the boom-crime relationship and has been informed by official data from government sources and qualitative data collected from interviews of human service workers and individuals receiving their assistance, including survivors of intimate partner and domestic violence. Our review of the extant literature reveals the presence of five community conditions that likely interact to exacerbate the volume and seriousness of violence toward women in boomtowns, including: (a) precarious housing arrangements; (b) the social isolation of women; (c) lack of domestic violence shelters and other social supports; (d) a workplace culture in the oilfields supportive of substance abuse and hyper-masculinity, and; (e) the inability of boomtown justice systems to respond to these crimes in an effective or timely manner. Feminist theory posits that gender stratification, whether it be social, economic, or legal, marginalizes women and leads to female victimization (Irwin \& Chesney-Lind, 2008), and intersectional theory expands this argument to show how multiple structures of dominance (e.g., race, ethnicity, and class) compound the disadvantages experienced by minority women (Bernard, 2013). Consistent with these arguments, we contend these factors, shown in Figure 1, are likely to raise the risk of interpersonal violence and exacerbate the harm produced in its aftermath. Identifying these conditions is the first step in developing theoretical explanations for violence in boomtowns. The following section summarizes these factors. 
Figure 1: Factors Contributing to Violence Toward Women in Resource-Boom Areas

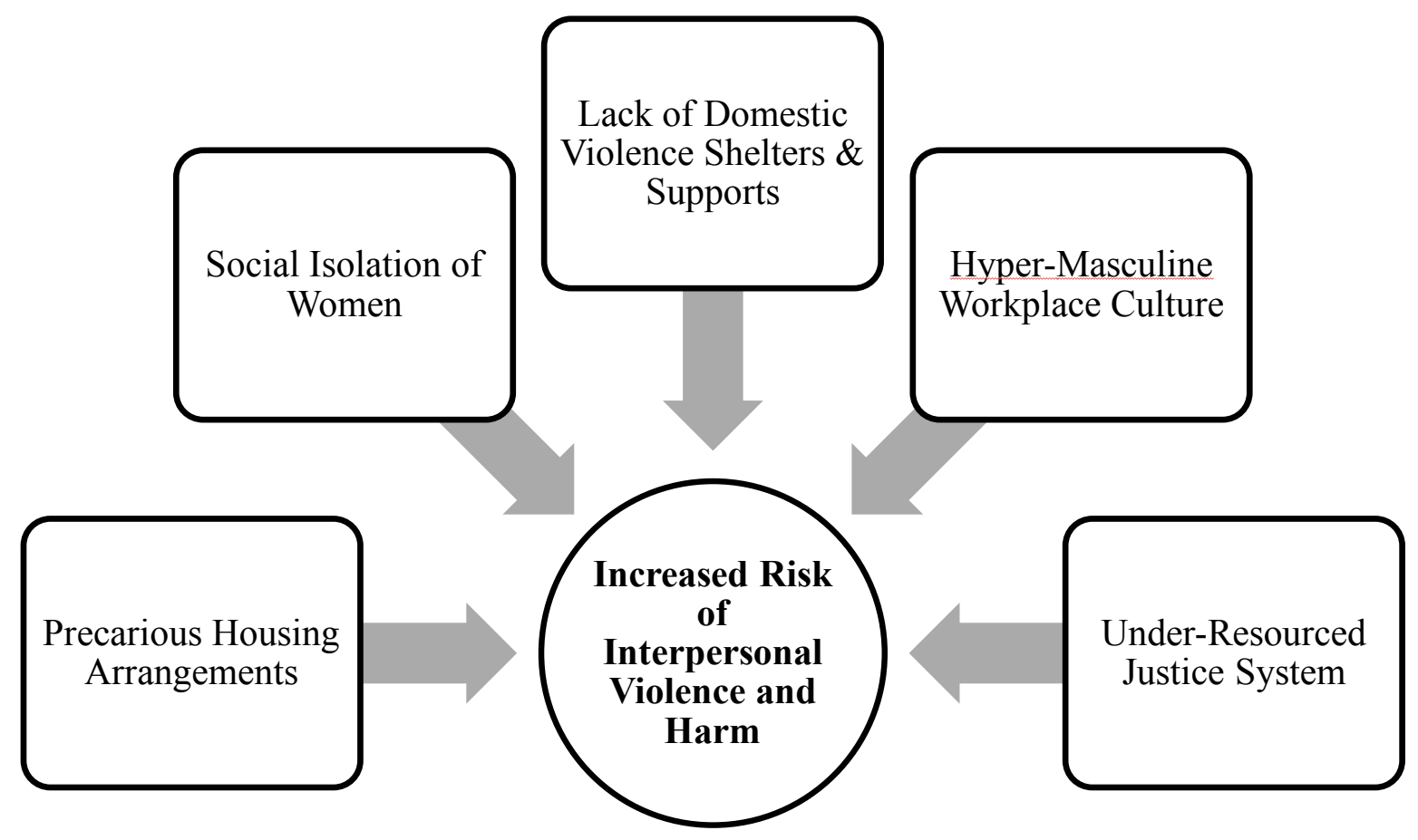

\section{Precarious housing arrangements}

The rapid population growth in a community due to an influx of newcomers is the most disruptive aspect of a resource-based boom (Murphy et al., 2018). Few rural communities can accommodate the inflow of incoming workers and housing shortages lead to several negative outcomes. The first is that housing and rental costs increase, and temporary accommodations such as hotels become unaffordable as corporations, who can afford to pay the inflated rates to house their workers, rent all the available rooms. Some permanent residents, such as seniors or individuals on fixed incomes, leave the community after their living costs become unaffordable. Subsidized housing is seldom a viable option for newcomers or permanent residents as the rates paid by the government are a fraction of the inflated market prices (Jayasundara et al., 2018). Losing permanent residents, and especially seniors, due to unaffordable housing reduces the informal social control in these communities. Moreover, many of these seniors provide low-cost childcare to their families, as well as engage in other voluntary activities, and thereby are important in maintaining community stability. 
Makeshift housing arrangements in a boomtown become commonplace. Residents live in their vehicles in shopping mall parking lots, campgrounds quickly fill-up with workers, and it is common for several individuals to share a single room. Commuting becomes normative and many workers will drive-in and drive-out (DIDO) to their permanent residences after their shift rotations end (many oilfield personnel are in schedules such as two weeks working followed by one week off). Man camps, which is housing for oilfield workers, are founded on the periphery of some boomtowns, and these camps can vary from informal arrangements - such as hundreds of camper-trailers in a farmer's field - or they can be more long-lasting structures, such as employer-supplied dorms featuring individual bedrooms and offering dining and recreational facilities (Power \& Power, 2019). While employer-supplied man camps tend to be alcohol-free places, some camps are chaotic, and one oil field worker explained they are "indescribable, the stuff that happens, there are shootings, stabbings, rapes, fights, extreme amounts of drugs, alcohol" (as cited in Bleir \& Zoledziowsky, 2018, para. 66).

Women's living arrangements in rapid growth communities have been described as lacking stability and often they live with their partners and children in homes occupied by several families or in small camper-trailers that might only be 8 ' by 12 ' in size. Crowded living arrangements can increase family tensions and a respondent in an Amnesty International (2016) report observes that "You'd be surprised how many women are just one argument with their spouse away from being on the streets" (p. 43). Some women are placed on the street after police are called to incidents of domestic violence occurring in employer-supplied housing. While it is customary to remove the aggressor from a shared residence after incidents of domestic violence, in cases where the housing is part of an oilfield worker's employment benefits, the woman - who is apt to be the victim and less likely to be employed in the oilfield — must be removed as she has no right to live in that housing.

Section 8, or subsidized housing, is an option for victims of family violence, but after a boom occurs these benefits are almost impossible to access. In their analysis of housing in the Bakken, Jayasundara et al. (2018) found that eligibility restrictions prevented some survivors from accessing this housing as landlords opted out of the Section 8 program after rents increased. As a result, even when survivors of family violence are approved for subsidized housing, they are unable to find lodging within the approved budget.

Commenting about domestic violence in North Dakota boomtowns Rendahl (2015) observes "The lack of housing options becomes a central theme in a victim's ability to seek protection from her abuser, find a safe place, and ultimately leave the situation" (p. 124). Because there are so few safe and affordable housing alternatives in a boomtown, survivors of abuse may be reluctant to leave their abusers as they will become homeless. This lack of options is not lost on abusers who can use their spouse's vulnerability to reinforce the power imbalances in their relationships.

\section{Social isolation}

Women in boomtowns can become socially isolated due to the community's characteristics, their status as marginalized persons, or their inability or reluctance to engage with others in neighborhood activities. Persons with limited social networks of friends or 
relatives are vulnerable to abuse as they have limited social support and abusers can exploit this isolation. This social isolation can be attributed to several conditions occurring in boomtowns. Newcomers, for example, are not always accepted by long-term community residents who can be dismissive, antagonistic, or hostile as they see temporary residents as reducing their quality of life and disrupting their ways of life (Huynh et al., 2019; O'Connor, 2015). Ruddell (2011) reports that newcomers are sometimes given stigmatizing labels such as rig pigs, gas-holes, and oilfield trash. Acceptance of newcomers might be further reduced for individuals who come from different ethnic or racial groups. Genareo and Filteau's (2016) interviews of boomtown community members who were overwhelmingly White revealed that they preferred to interact with 'people like us.' These perceptions may contribute to the social isolation of newcomers (see also O'Connor, 2015).

A reluctance to engage with others may also be due to a lack of English language skills or an inability to access translators. As an example of the growing language heterogeneity in a boomtown, Cohen (2014) reports a North Dakota school official saying that "kids from all 50 states Yemen, Egypt, Russia, Pakistan, Mexico, India, and China, have attended the school" (para. 5). Depending on their circumstances, the parents of these children may have less developed English language skills than their children.

Members of marginalized populations who fear or distrust the police may be further isolated. Non-citizens, for example, may be hesitant to attract any police attention in fear of being detained or deported, or because they fear losing their children (Bramadat, 2015). There is a long history of distrust between Indigenous peoples and the police. Indigenous peoples account for slightly less than 10 percent of the North Dakota state population (U.S. Census Bureau, 2018) while at least one-quarter of all oil is extracted from tribal lands (U.S. Energy Information Administration, 2020). There is growing evidence that women on tribal lands are at increased risk of victimization (Jayasundara, Heitkamp, et al., 2016). As few non-native persons are held accountable for crimes they commit on tribal lands, Native Americans may be reluctant to report their victimization to the police (see Finn et al., 2017 below).

Women living in rural areas might also be at higher risk of victimization irrespective of whether natural resources are being extracted. DeKeseredy et al. (2016) find that rural women are at higher risk of non-lethal and lethal violence compared to their counterparts living in more populated areas. DeKeseredy (2019) contends that violence toward rural women is higher due to the protection of the perpetrators by a predominately male justice system ('the good old boys'), their geographic and social isolation, the broad acceptance of patriarchal attitudes, a tolerance for domestic partner abuse and a refusal to support battered women seeking assistance, high rates of male viewers of pornography, and a lack of public transportation that makes it difficult for survivors to obtain help. Resource-based booms likely exacerbate some of these conditions and further reinforce the patriarchal and hyper-masculine attitudes, which are described below.

The contribution of resource-based booms and social isolation to family violence has long been recognized. Endo et al. (1984) identified this problem in the 1970s era boomtowns and found that men with alcohol problems and those involved in assaults in the community were also more likely to engage in family violence. Unequal power dynamics in relationships can also reinforce an individual's social isolation as unemployed women, or those in low-paying jobs, are 
highly dependent upon their male partners (Titterington, 2006) and can't afford to access resources that would allow them a way out (Dugan et al., 1999). This dependency can pressure them to stay in unhealthy or violent relationships. A respondent in the Amnesty International (2016) report, for example, refers to herself as an "economic hostage" (p. 43).

\section{Lack of domestic violence shelters and support services}

One of the most predictable outcomes of a boom is the inability of local governments to manage the demands placed on their human service agencies (Weber et al., 2014), first responders (Cwiak et al., 2015), and the justice system (Jayasundara, Heitkamp, et al., 2016; Ruddell, 2017). The rapid population growth increases the demand for services, and rural health facilities and schools quickly become overwhelmed with new patients and students. Social service agencies also experience a rising demand and the clients requesting services often have a greater number of unmet needs than clients from their traditional caseloads (Jayasundara, Heitkamp, et al., 2016). Non-profit organizations face similar challenges. In addition to increasing the volume and seriousness of the unmet needs presented by their clients, many boomtown residents also suffer from the effects of substance abuse. Heitkamp (2016) describes how the growing prevalence of illicit drugs in Montana and North Dakota boomtowns contributes to crime and has exacerbated the extent and seriousness of all community problems, including domestic and intimate partner violence (see Maryfield et al., 2019).

Rendahl (2015) reports that in the pre-boom era emergency shelters were rarely used, but demand has increased to the point where these housing services were overcrowded and in constant use. Another challenge Rendahl identifies was that most North Dakota domestic violence services acted as referral agencies that sent their clients to receive counseling and other supportive services from other organizations. Few of those affiliated agencies, however, had received additional personnel to manage their growing caseloads in the early stages of the boom despite the increased demand. As a result, these supportive services were rationed, and the time to get an appointment to see a counselor increased from days to weeks (Rendahl, 2015). In order to access these services, some clients were expected to travel to larger cities; making it difficult for women without transportation.

Conlin (2014) notes there were no government-operated homeless shelters in the North Dakota cities that were the epicenters of the oil boom, although some charitable and religious organizations provided emergency beds. One distressing finding from the interviews and focus groups of human service personnel analyzed by Jayasundara, Heitkamp, and Ruddell (2016) was that some survivors of domestic violence were unable to access emergency shelters, and beds were only available for women with children. Single women without children, by contrast, were unlikely to receive any emergency housing. This lack of services extends to survivors of human trafficking and in 2014 the nearest shelter for these people was 500 miles from the North Dakota oil fields (Dalrymple \& Lymn, 2015).

The challenges of managing human service caseloads in a boom community are magnified in rural areas. Some rural clients find it difficult to get to appointments if they lack transportation or during inclement weather. Human service workers, by contrast, spend more time travelling to carry out home visits and arranging visits between children in care and their parents. The 
distances traveled are often measured in hours and the human service workers call this windshield time. Visits to their clients can be further challenged when they are living in makeshift housing arrangements, such as a travel trailer in a campground with several hundred other trailers and recreational vehicles, but no formally labeled streets or numbered trailers (Jayasundara, Heitkamp, \& Ruddell, 2016). Not only is finding their clients challenging, but these workers often request the assistance of the police for some home visits, and while this is an important step in bolstering their safety, one home visit can take an officer off the streets for several hours once travel time is considered.

Lacking the ability to access housing or other services and supports, many survivors of abuse who are not originally from the Bakken are provided with bus tickets to their hometowns from some human service agencies or community organizations such as the Salvation Army (Conlin, 2014). Although the practice of returning individuals to their home states reduces demand for community services, it creates a challenge for prosecutors who need the testimony of these victims to convict their abusers.

\section{Workplace culture that supports substance abuse and hyper-masculinity}

The workplace culture in places undergoing resource-based booms is often described as having a male-centric "work hard and play hard" environment fueled by alcohol and drugs (Amnesty International, 2016). A report by the Boston Consulting Group found that $78 \%$ of employees in the oil and gas industry and $89 \%$ of the employees in the construction business were male (Rick et al., 2017). A respondent in the Amnesty International (2016, p. 44) study of resource-based places observes that "How hard you work, how much you party, and how many toys you have - that's oil patch culture." The Amnesty International researchers observe that the physical and psychological demands placed on workers during their shift rotations (often working two weeks of 12 hour-days with one week off to follow) and the accumulated stress is akin to a pressure cooker and on their time off they want to blow off steam, which often involves drinking and drug use. This substance abuse and feeling of entitlement to be free of domestic concerns is associated with a greater likelihood of violence toward their intimate partners and family members. Tensions sometimes develop between family members as the worker on their first day off wants to blow off steam whereas their partner wants a break from childcare and wants them to provide that support (Amnesty International, 2016).

Historically, most substance abuse problems in the oilfields and the resource-based booms preceding them were associated with alcohol abuse, and while marijuana was regularly used, cocaine, heroin, or methamphetamines were less commonly encountered. Although Mayer and Hazboun (2019) found that higher rates of alcohol abuse are still associated with fracking in some boom counties, the types of substance abuse have changed. Farrell (2005), for example, observes that "methamphetamine fuels the west's oil and gas boom" and cites a long-term oilfield worker as saying that "Either you're wired or you're fired" (para. 15). Nichols and Soper (2007) report that the police in Colorado came into increased contact with methamphetamine users after 2003 and many of these individuals worked in the oil and gas industries. Law enforcement officials in the Texas oilfields also experienced an influx of methamphetamine after the 2008 energy boom (Hampton, 2017; Paraskova, 2018). One reason for the increased use of methamphetamine and similar drugs is their ability to flush through a user's system in several 
days, whereas marijuana can be detected in drug tests for much longer (U.S. Food and Drug Administration, 2017). Thus, workers fearful of a positive drug test may be more likely to use methamphetamine than marijuana.

Heitkamp (2016) observes that there has been a significant increase in methamphetamine use in the Bakken and its prevalence extends beyond the oilfields. A review of crime statistics from the Attorney General of North Dakota (2016) reveals that the number of methamphetamine violations grew from 246 in 2010 to 1,633 in 2015 (p. 2). In Montana, the number of drug offenses increased by $86 \%$ during the same era (statistics on methamphetamine-related offenses were not available for Montana - see Montana Board of Crime Control, 2019). Maryfield et al. (2019) found that the methamphetamine-related offenses reported by the police more than tripled between 2012 and 2014 in oil-impacted counties in the Bakken region, although there was also a spillover effect with surrounding counties. Their analyses revealed that these drugs were being distributed by Mexican drug trafficking operations and were particularly destructive on tribal lands, where officials called the increased use of methamphetamine an epidemic (Maryfield et al., 2019).

There is some debate about the extent of the work hard and play hard culture in the oilfields. Angel (2014) contends that many of the stereotypes associated with a transient workforce are inaccurate and most oilfield workers today are family-oriented. Furthermore, employers are less tolerant of substance abuse, and an increasing percentage of employersupplied housing units forbid alcohol use and drug detection dogs are used to search company housing and job sites to keep them drug-free (Hackenburg, 2017). Police officers in the Archbold et al. (2014) study remind us that only a small percentage of the newcomers are engaging in offenses and that long-term boomtown residents also contribute to community crime.

Other destructive patterns encountered in boom communities involve "hyper-masculinity and hyper-femininity in which harmful stereotypes of men as the breadwinner and women as the homemaker are played out in exaggerated extremes" (Amnesty International, 2016, p. 43). These gender roles are reinforced by an industry culture that presents numerous barriers to female employment (Rick et al., 2017). In their analysis of gender relations in the Bakken region, Pippert and Zimmer Schneider (2018) describe a masculine culture based on risk-taking, excessive alcohol use, financial greed, and sexual conquests. Similar traits were defined by Angel (2014) as a frontier masculinity "associated with resource extraction contexts and is characterized by physical and mental toughness, rugged individualism, competition, emotional self-reliance, and unsafe work practices that save time and maximize profit" (p. 3). Bradshaw et al. (2017) label these traits as supernormal patriarchy with respect to extractive industries, and propose that the dangerous, difficult, and demanding nature of this work contributes to these behaviors.

Hyper-masculinity is associated with a higher involvement in violence, particularly sexual violence (Pazzani, 2007) and this trait has been documented in extractive industries across the globe. Carrington et al. (2016) observed the link between a frontier masculinity and aggressive behavior in rural Australian mining towns. These scholars contend that a monolithic form of masculinity can emerge in these settings that strictly defines male and female roles, and this can escalate tensions between long-term community residents and newcomers, as well as increase 
gendered violence. Thus, a male-centric industry culture as well as its context in rural settings may contribute to increased levels of interpersonal violence, as well as a reluctance to report domestic violence when it does occur.

\section{Under-resourced justice system}

A review of the extant literature reveals that the criminal justice system in boomtowns is often overwhelmed and the police, courts, or local corrections are often unable to manage the volume of cases generated by the increased demands contributes to higher levels of crime, including violence toward women. In terms of law enforcement, for example, police departments and sheriff's offices are seldom able to keep up with calls for service (Archbold et al., 2014; Covey \& Menard, 1984; Dahle \& Archbold, 2015). Archbold et al. (2016) found that in Williston, North Dakota, one of the epicenters of the boom, the calls for service increased by $858 \%$ between 2000 and 2013 but the police department only added $81 \%$ more officers to manage that workload. Moreover, it may take years before police staffing levels match the population increase in a boom community (Ruddell, 2011). In the meantime, officer turnover is high, which places further demands on agency leaders to recruit and train additional officers. Interviews with law enforcement officials reveal that after a boom occurs the threshold for arrests increases and police are forced to prioritize more serious crimes (Archbold et al., 2014). Although most of the crimes in boomtowns are misdemeanor offenses, the sheer volume of the workload forces officers to go from call to call without much time to investigate non-felony offenses or engage in any proactive crime control strategies.

Failing to manage the demands on the police, courts, and corrections contribute to violence toward women as cases fall through the cracks of the system and people who commit crimes go unpunished and victims' needs go unmet. Perceptions of justice are important because if the public believes that a state of lawlessness exists some individuals might feel emboldened to act aggressively. When it comes to cases falling through the cracks in the justice system, the North Dakota Court System (2016) observes that the dockets for criminal and civil matters increased after the start of the oil boom. Perry (2007) describes how it took several years before staffing caught up with the increased demand after a resource-based boom occurred in Wyoming. As a result, some cases are not heard for a year or longer. Defendants, victims, and witnesses — who may all be transient or non-permanent residents - can disappear before a trial is held and these cases may never proceed. Furthermore, domestic violence has the potential to escalate and victims may be stuck in situations where they are at increased risk while waiting for a response from the justice system. Dewey et al. (2019) note that these conditions also lead to female criminality, as socially isolated victims may resort to self-medication and retaliatory violence to defend themselves.

Probation agencies, which are also funded at the county-level in most states, become overwhelmed during a boom (Guldborg, 2016). Most individuals appearing before boomtown courts are sentenced to probationary sentences for their involvement in misdemeanor offenses and research shows that providing effective community supervision reduces recidivism (Smith et al., 2018). When asked about the impact of the oil boom on community supervision, however, North Dakota officers report that caseloads increased and much of that increase was due to outof-state probationers (Buchholz, 2016). Buchholz (2016) also found that probation and parole 
officers relaxed their requirements in terms of supervision and were more lenient: one officer remarked "Offenders get away with a lot more than they have ever before" (p. 124). Last, when Buchholz (2016) examined the outcomes of parolees released from prison during the pre-boom and post-boom eras, the ones released during the peak of the oil boom in 2013 were more likely to recidivate than those released in 2006.

Having enough personnel to meet demand and provide effective supervision enables probation agencies to dedicate caseloads to domestic violence offenders. Adequately staffing these agencies also enables judges to sentence these individuals to community-based sentences rather than relying upon incarceration, thereby reducing demands on the local jails. The same challenge exists for courts as there are few domestic violence courts in small towns. A review of a national Bureau of Justice Statistics report reveals there were no domestic violence courts in Montana or North Dakota in 2012 (Strong et al., 2016). Yet, even when that specialization exists, it must also be supported by community resources, such as substance abuse treatment, and Buchholz (2016) observes those resources were stretched thin after the boom.

In terms of managing intimate partner and family violence cases, rural law enforcement agencies also lack specialization and training. Reaves (2017) reports that about one in ten police departments or sheriff's offices in jurisdictions of less than 10,000 residents had units with fulltime personnel specializing in domestic violence cases. Training might enhance the knowledge and skills of the responding officers, but over one-half of the officers in the Dooley and Ruzinka (2013) study report they were unable to attend training due to inadequate staffing, while about one-quarter say they did not have the time to attend any of these learning opportunities. These scholars argue that a lack of training results in inconsistent treatment of suspects and victims, as well as how these incidents are documented. Dooley and Ruzinka (2013,) further observe that "improving responses to domestic violence incidents in rural and small-town police departments is challenging when a lack of personnel and resources prevent the development of extensive protocols, units, and training from progressing" (p. 4). The potential for secondary victimization, where individuals report their initial victimization and then are re-traumatized by their interactions with the criminal justice system in these situations is high (see Herman, 2003).

Results from the national crime victimization survey reveal that domestic violence and intimate partner assault rates have been increasing (Morgan \& Oudekerk, 2019). However, a comparison of victimization and police data for the entire nation suggests about $56 \%$ of these offenses are reported to the police, and 39\% of these acts end in an individual being charged or arrested (Reaves, 2017). Reporting rates for violent crimes toward women may be lower in places where women have less faith in the justice system or if there are barriers to the police acting on these reports (Dowling et al., 2018).

With respect to structural barriers to pursuing justice, the plight of Native American women deserves special attention. As noted above, about one-quarter of oil extraction activities in the Bakken occur on tribal lands. One of the most serious shortcomings in investigating and prosecuting violent crimes toward Native American women occurring on tribal lands happens if they are perpetuated by non-Indigenous persons. Finn et al. (2017) observe that tribal law enforcement agencies are often powerless to prosecute criminal activities carried out by nonIndigenous persons on reservations. This is because of historical arrangements that did not allow 
tribal police services to arrest non-Natives. Although the 2013 reauthorization of the Violence Against Women's Act gave tribal authorities the authority to arrest and prosecute non-natives who commit crimes against Native American women they know-such as intimate partnerstribal police do not have jurisdiction over cases where the victim is unknown to the perpetrator and those cases are referred to the federal government (or the state government in six states). On February 19, 2019, the Violence Against Women's Act reauthorization expired and it had yet to be reauthorized by July 2020 .

\section{Discussion}

Our review of the extant literature and our experiences in studying boomtown crime and community dynamics led us to identify five factors that are associated with increases in domestic and intimate partner violence in Bakken communities experiencing resource-based booms. These factors are consistent with existing feminist theoretical work that links gender stratification and patriarchy to female victimization (Irwin \& Chesney-Lind, 2008). Several scholars have noted that dynamic social change, female economic dependence on men, rural criminal justice agencies that are unprepared for rapid or diverse population growth, and the social isolation of women in boomtowns present a unique environment that exacerbates domestic violence (Dewey et al., 2019; DeKeseredy \& Schwartz, 2009). Furthermore, the importance of the intersectionality of social oppression in terms of gender, race, culture, and legal status plays a role in victims' abilities to seek help and the responses victims receive from criminal justice and social service agencies in boomtowns (Charman, 2019).

Knowing that these five conditions coalesce in boomtowns to increase violence toward women is important to develop violence reduction strategies in these places. These strategies must be developed with the understanding that all the social ills associated with booms are highly interconnected. It is important to draw on feminist theory and an understanding of intersectionality to develop trauma-informed criminal justice and community organization responses that can intervene in patterns of violence common in boomtowns. Writing about 1970s era resource-based boomtowns, Gilmore (1976) observes that it is almost impossible to tackle any one of these issues without confronting the others. As a result, strategies intended to mitigate boomtown effects must be broad-based and start with an understanding that booms have a life course and all resource-based booms ultimately end (Ruddell \& Ray, 2018). Given that observation, a key priority for local government officials is ensuring they reduce the potential harms to their communities while booms are occurring and prepare for the inevitable loss of revenue after resource extraction activities decrease.

One of the challenges of managing a resource-based boom is that officials in these communities are seldom prepared for the demands placed on their government services. As a result, they often become overwhelmed and act reactively. We also must understand that many of these officials carry out these duties on a part-time or voluntary basis and seldom have the expertise required to manage the social ills associated with the rapid growth and industrialization in a boomtown (Morrison et al., 2012). Developing a body of literature that allows public safety officials, and non-profit and industry leaders to predict the types of issues, like increasing levels of domestic violence can be the first step toward training, prevention, and planning efforts to better serve boomtown communities. In addition to drawing on feminist theory to explain why 
boomtown gender-stratification leads to a host of societal ills and for insight into the creation of policies and practices that reduce inequality and value diversity, routine activities theory and crime prevention through environmental design can be used by law enforcement agencies to focus on prevention and allocate limited resources more efficiently.

The anticipation of a resource-based boom is often met with optimism that the enhanced economic activity will cover the costs of the expanded services required to meet the demands of a rapidly growing population. The economic benefits in the initial stage of a boom, however, are seldom able to match the rising demand on public services given the lag for tax revenues to increase. The problem confronting local governments is that the best return for the taxpayer's investments in human service spending, including criminal justice expenditures, is achieved before the social and crime-related problems escalate.

Given the revenue shortfalls in the initial stages of a boom, there are several steps local governments can take to mitigate boomtown effects. Local governments should be encouraged to collaborate with neighboring jurisdictions to share resources to leverage their impact (see Smith et al., 2019 for an evaluation of this approach). Thus, several counties working together to develop a regional domestic violence shelter, for example, may enhance services at a lower cost than several towns or counties attempting to go it alone and delivering services in separate standalone facilities. A second strategy to enhance service delivery is for local governments to partner with as many external agencies as practical in the earliest stage of the boom. Rural law enforcement and human service agencies often lack the personnel or the expertise to manage the rapid population growth and the concomitant social problems. As a result, partnering with organizations from surrounding jurisdictions, state or federal agencies, as well as the security forces from the oil and gas or mining industries may prove fruitful.

Local governments must also acknowledge the importance of services provided by volunteers in sparsely populated rural communities and nurturing their efforts should be prioritized. Cwiak et al. (2015) describe the overwhelming physical and psychological demands placed on volunteer first responders in North Dakota counties due to the increased numbers of industrial accidents and traffic collisions occurring after the boom. The high costs of living in boomtowns can also lead to an out-migration of established community residents, including "volunteer firefighters, foster parents, volunteer aids and church ladies" (Flanagan et al., 2014, p. 100). In addition to bolstering the efforts of all human service agencies and increasing the quality of community life, these individuals may play an important role in reducing the social disruption occurring in these places.

Similarly, industries that drive boomtowns also have a role to play in changing the malecentric culture arising in these areas. Efforts should be made to diversify the oil and gas, construction, and mining industries by hiring and supporting women at all levels (Rick et al., 2017). Additionally, a greater emphasis should be placed on sexual harassment training and creating less hostile living and working environments. Industries should be encouraged to partner with communities and help support non-profit organizations and efforts to combat substance abuse, interpersonal violence, as well as supporting healthy communities and families. 
Ruddell (2017) contends that boomtown crimes tend to stabilize over the long-term but that all resource-based booms eventually end when extraction activities are no longer profitable. Writing about mining operations, Andrews-Speed et al. (2005) observe that "mine closure needs to be an integral part of the planning for the whole life of the mine" (p. 40). Although we know less about the criminological impacts after the oil wells or mines cease production and an economic bust occurs, there is mounting evidence about increases in domestic violence after these events occur, including accounts after the 2014 oil and gas industry downturn in Canada (Canadian Broadcasting Corporation, 2015; Graveland, 2016; Urwin, 2016) and the U.S. (O'Donoghue, 2016). These surges in domestic violence are attributed to the tensions occurring after family members lose their jobs and financial pressures expand. Increases in family violence after an oilfield bust are similar to those occurring after the 2008 recession (Buzawa \& Buzawa, 2013; Police Executive Research Forum, 2013; Schneider et al., 2016).

Altogether, we observe that both the economic boom and bust in these rural communities may contribute to higher levels of domestic violence. One of the limitations of our observations about domestic violence in these rapid growth communities, however, is that they lack empirical support. Having acknowledged that shortcoming, our observations provide a framework that is consistent with feminist theory, for researchers to examine how these five community-level factors contribute to violence toward women during a boom, and after the inevitable economic bust.

\section{Conclusion}

The issue of boomtown crime is topical today as high commodity prices continue to drive resource exploration and extraction activities across the globe. Not only is there a demand for traditionally mined minerals such as oil and gold, but green technologies are expanding the demand for commodities such as lithium (used for batteries) and rare earth materials used in the manufacture of cellular phones and electronic vehicles. It is estimated that the demand for these minerals will increase tenfold by 2050; so even reduced use of fossil fuels will not decrease mining activities (Hodgkinson \& Smith, 2018). As many of the places where these resources are mined are rural it is likely that these boomtowns and the related community risk factors will continue to emerge across the globe for the foreseeable future. These communities will confront the same set of challenges that led to increased levels of violence toward women in the Bakken region. Given there is a predictable set of outcomes, they can be mitigated by forward-looking local government officials, industry, and non-profit stakeholders. The key question is whether there is the political willingness to act proactively to reduce the risk to these women? 


\section{References}

Adamson, R. (2017). Vulnerabilities of women in extractive industries. ANTYAJAA: Indian Journal of Women and Social Change, 2(1), 24-31. https://doi.org/10.1177/2455632717714134

Amnesty International. (2016). Out of sight, out of mind: Gender, Indigenous rights, and energy development in northeast British Columbia, Canada. Author. https://www.amnesty.ca/sites/amnesty/files/Out $\% 20$ of $\% 20$ Sight $\% 20$ Out $\% 20$ of $\% 20$ Mind $\% 20$ EN\%20FINAL\%20web.pdf

Andrews-Speed, P., Ma, G., Shao, B., \& Liao, C. (2005). Economic responses to the closure of small-scale coal mines in Chongqing, China. Resources Policy, 30(1), 39-54. https://doi.org/10.1016/j.resourpol.2004.12.002

Angel, A. C. (2014). Beyond the "roughneck" stereotype: Revealing the actual face of mobile workers in the Alberta oil sands and North Dakota's Bakken oil region and why it matters to health. Target Logistics.

Archbold, C. A., Dahle, T., Huynh, C., \& Mrozla, T. (2016). "Some days I feel like the dam broke:" An examination of increased workload on police officer stress and job satisfaction in western North Dakota. Internet Journal of Criminology Special Issue on Boomtowns, 49-71.

Archbold, C. A., Dahle, T., \& Jordan, R. (2014). Policing "the patch": Police response to rapid population growth in oil boomtowns in western North Dakota. Police Quarterly, 17(4), 386-413. https://doi.org/10.1177/1098611114549629

Attorney General of North Dakota. (2016). 2016 comprehensive status and trends report. Author.

Attorney General of North Dakota. (2020). Crime and homicide reports (various years). https://attorneygeneral.nd.gov/public-safety/crime-data/crime-reports

Bernard, A. (2013). The intersectional alternative: Explaining female criminality. Feminist Criminology, 8(1), 3-19. https://doi.org/10.1177/1557085112445304

Bleir, G., \& Zoledziowski, A. (2018, Aug. 27). The missing and murdered: 'We as Native women are hunted.' Carnegie-Knight. https://www.indianz.com/News/2018/08/27/themissing-and-murdered-we-as-native-wo.asp

Bradshaw, S., Linneker, B., \& Overton, L. (2017). Extractive industries as sites of supernormal profits and supernormal patriarchy? Gender \& Development, 25(3), 439-454.

https://doi.org/10.1080/13552074.2017.1379780 
Bramadat, J. (2015). The role of Canadian laws and social policies in perpetuating intimate partner abuse against newcomer women. (Unpublished master's thesis). University of Manitoba.

Britto, S. (2016). Finding the town amidst the boom: Public perceptions of safety and police priorities in a boomtown milieu. Internet Journal of Criminology Special Issue on Resource-Based Boomtowns, 9-26.

Buchholz, M. (2016). Blessings and curses: The impact of the North Dakota oil boom on offender reentry and reintegration into the community. (Unpublished doctoral dissertation). North Dakota State University.

Buzawa, E. S., \& Buzawa, C. G. (2013). What does research suggest are the primary risk and protective factors for intimate partner violence (IPV) and what is the role of economic factors? Journal of Policy Analysis and Management, 32(1), 128-137. https://doi.org/10.1002/pam.21668

Canadian Broadcasting Corporation. (2015, Nov. 6). Domestic violence calls in Calgary spike during good times and bad. CBC News. https://www.cbc.ca/news/canada/calgary/oilboom-bust-domestic-violence-1.3306360

Carrington, K., Hogg, R., \& Scott, J. (2016). Alcohol, violence, frontier masculinities and the Australian mining boom. Internet Journal of Criminology Special Issue on ResourceBased Boomtowns, 94-124.

Charman, M. (2019). Gendered boomtown impacts: a social service perspective of women in resource extraction communities. (Unpublished master's thesis). Ontario Tech University.

Cohen, S. (2014). Growing pains: Oil boom turns prairie school to melting pot. Associated Press. http://bakken.com/news/id/232893/growing-pains-oil-boom-turns-prairie-school-meltingpot/

Conlin, M. (2014, Feb. 11). Hot economy, cold comfort: North Dakota's homeless problem. Reuters. https:/www.reuters.com/article/us-homelessfinal-north-dakota/hot-economycold-comfort-north-dakotas-homeless-problem-idUSBREA1A1OT20140211

Covey, H. C., \& Menard, S. (1984). Response to rapid social change: The case of boomtown law enforcement. Journal of Police Science and Administration, 12(1), 164-169.

Cwiak, C. L., Avon, N., Kellen, C., Mott, P. C., Niday, O. M., Schulz, K. M., \& Webb Jr., T. B. (2015). The new normal: The direct and indirect impacts of oil drilling and production on the emergency management function in North Dakota. North Dakota State University. https://www.ndsu.edu/fileadmin/emgt/FINALThe_New_Normal_January_2015_a.pdf 
Dahle, T., \& Archbold, C. A. (2015). Just do what you can...make it work! Exploring the impact of rapid population growth on police organizations in western North Dakota. Policing: An International Journal of Police Strategies \& Management, 38(4), 805-819. https://doi.org/10.1108/PIJPSM-03-2015-0037

Dalrymple, A., \& Lymn, K. (2015, Jan. 4). Sex for sale in the Bakken. The Forum. http://www.traffickedreport.com/wp-content/uploads/2015/02/TraffickedOpti.pdf

Deer, S., \& Nagel, M. K. (2017). The rapidly increasing extraction of oil, and native women, in North Dakota. The Federal Lawyer, 64(April), 35-37.

DeKeseredy, W. S. (2019). Intimate violence against rural women: The current state of sociological knowledge. International Journal of Rural Criminology, 4(2), 312-331. https://doi.org/10.18061/1811/87904

DeKeseredy, W. S., \& Schwartz, M. D. (2009). Dangerous exits: Escaping abusive relationships in rural America. Rutgers University Press.

DeKeseredy, W. S., Hall-Sanchez, A., Dragiewicz, M., \& Rennison, C. M. (2016). Intimate violence against women in rural communities, in J. Donnermeyer (ed.), The Routledge International Handbook of Rural Criminology (pp. 171-180). Routledge. https://doi.org/10.4324/9781315755885-20

Dewey, S., Zare, B., Connolly, C., Epler, R., \& Bratton, R. (2019). Outlaw women: Prison, rural violence, and poverty in the American West. New York University Press. https://doi.org/10.18574/nyu/9781479801176.001.0001

Dooley, L., \& Ruzinka, R. (2013). Law enforcement survey on domestic violence and sexual assault. Rural Crime and Justice Center. https://pdfs.semanticscholar.org/94f4/b59b82d7a62d3eb76a783c8204613e509dde.pdf?_g $a=2.9632310 .2033171347 .1593037116-618875599.1593037116$

Dowling, C., Morgan, A., Boyd, C., \& Voce, I. (2018). Policing domestic violence: A review of evidence. Australian Institute of Criminology. https:/www.aic.gov.au/publications/rr/rr13

Dugan, L., Nagin, D., \& Rosenfeld, R. (1999). Explaining the decline in intimate partner homicide. Homicide Studies, 3(3), 187-214. https://doi.org/10.1177/1088767999003003001

Endo, R., Ellington, B. L., \& Neilson, J. M. (1984). Wife abuse in western energy boomtowns. International Journal of Sociology of the Family, 14(2), 269-281.

Farrell, P. (2005). Methamphetamine fuels the West's oil and gas boom. High Country News. https://www.hcn.org/issues/307/15811

Federal Bureau of Investigation. (2019). Crime in the United States, 2018. Author. 
Finn, K., Gajda, E., Perin, T., \& Fredericks, C. (2017). Responsible resource development and prevention of sex trafficking: Safeguarding native women and children on the Fort Berthold Reservation. Harvard Journal of Law and Gender, 40(1), 1-51. https://scholar.law.colorado.edu/cgi/viewcontent.cgi?article=1671\&context=articles

Flanagan, K., Heitkamp, T., Nedegaard, R. C., \& Jayasundara, D. S. (2014). Black gold and the dark underside of its development on human service delivery. Contemporary Rural Social Work, 6(1), 86-106. https://digitalcommons.murraystate.edu/crsw/vol6/iss1/7

Freudenburg, W. R., \& Jones, R. E. (1991). Criminal behavior and rapid community growth: Examining the evidence. Rural Sociology, 56(4), 619-645. https://doi.org/10.1111/j.15490831.1991.tb00449.x

Genareo, V. R., \& Filteau, M. R. (2016). People like us: Shaping newcomer acceptance in rural boomtown communities and schools. The Journal of Rural and Community Development, 11(1), 43-55.

Gilmore, J. S. (1976). Boom towns may hinder energy resource development. Science, 191 (4227), 535-540. https://doi.org/10.1126/science.191.4227.535

Government of New Brunswick. (2012). Chief medical officer of health's recommendations concerning shale gas development in New Brunswick. Author. http://www.atlanticaenergy.org/pdfs/natural_gas/Environment/Chief\%20Medical\%20Offi cer\%20of\%20Health\%E2\%80\%99s\%20Report_NB_Sept\%202012.pdf

Graveland, B. (2016, Nov. 1). Police say increasing domestic abuse in Calgary tied to economic downturn. The Globe and Mail. https://www.theglobeandmail.com/news/alberta/policesay-economic-downturn-tied-to-increasing-domestic-abuse-in-calgary/article32622377/

Guldborg, A. (2016). Another day in the oil patch: Narratives of probation work in Montana. (Unpublished master's thesis). University of Montana.

Hackenburg, E. (2017, Mar. 10). Helping sniff out drug problems. Williston Herald. https://www.willistonherald.com/news/helping-sniff-out-drugproblems/article_694a9740-053b-11e7-82b8-5721ec6af379.html

Hampton, L. (2017, Sept. 6). Meth, coke, and oil: A drug boom in the Texas shale patch. Reuters. https://www.reuters.com/article/us-usa-oil-drugs/meth-coke-and-oil-a-drugboom-in-the-texas-shale-patch-idUSKCN1BI0F5

Heitkamp, T. (2016). White paper: Illicit drug use as a context. (Unpublished document).

Herman, J. (2003). The mental health of crime victims: The impact of legal intervention. Journal of Traumatic Stress, 16(2), 159-166. https://doi.org/10.1023/A:1022847223135 
Hodgkinson, J. H., \& Smith, M. H. (2018). Climate change and sustainability as drivers for the next mining and metals boom: The need for climate-smart mining and recycling. Resources Policy. https://doi.org/10.1016/j.resourpol.2018.05.016

Huynh, C., Robinson, C., Mrozla, T., Dahle, T. O., Archbold, C. A., \& Marcel, A. (2019). New faces in a new place: Long-term residents' perceptions of new residents in an oil boomtown in the Bakken oil shale region. Deviant Behavior, 40(8), 992-1006. https://doi.org/10.1080/01639625.2018.1456689

Irwin, K., \& Chesney-Lind, M. (2008). Girls' violence: Beyond dangerous masculinity. Sociology Compass, 2(3), 837-855. https://doi.org/10.1111/j.1751-9020.2008.00120.x

Jacquet, J. B. (2014). Review of risks to communities from shale energy development. Environmental Science \& Technology, 48(15), 8321-8333. https://doi.org/10.1021/es404647x

Jacquet, J. B., Junod, A. N., Bugden, D., Wildermuth, G., Fergen, J. T., Jalbert, K., Rahm, B., Hagley, P., Brasier, K. J., Schafft, K., Glenna, L., Kelsey, T., Fershee, J., Kay, D. L., Stedman, R. C., \& Ladlee, J. (2018). A decade of Marcellus shale: Impacts to people, policy, and culture from 2008 to 2018 in the greater mid-Atlantic region of the United States. The Extractive Industries and Society, 5(4), 596-609. https://doi.org/10.1016/j.exis.2018.06.006

James, A., \& Smith, B. (2017). There will be blood: Crime rates in shale-rich U.S. counties. Journal of Environmental Economics and Management, 84(July), 125-152. https://doi.org/10.1016/j.jeem.2016.12.004

Jayasundara, D., Heitkamp, T., Mayzer, R., Legerski, E., \& Evanson, T. (2016). Exploratory research on the impact of the growing oil industry in ND and MT on domestic violence, dating violence, sexual assault, and stalking. University of North Dakota. https://www.ncjrs.gov/pdffiles1/nij/grants/250378.pdf

Jayasundara, D., Heitkamp, T., \& Ruddell, R. (2016). Voices from the front line: Human service workers perceptions of interpersonal violence in resource-based boom counties. Internet Journal of Criminology Special Issue on Boomtowns, 72-93.

Jayasundara, D., Legerski, E., Danis, F. S., \& Ruddell, R. (2018). Oil development and intimate partner violence: Implementation of Section 8 housing policies in the Bakken region of North Dakota and Montana. Journal of Interpersonal Violence, 33(21), 3388-3416. https://doi.org/10.1177/0886260518798359

Keough, S. B. (2015). Planning for growth in a natural resource boomtown: Challenges for urban planners in Fort McMurray, Alberta. Urban Geography, 36(8), 1169-1196. https://doi.org/10.1080/02723638.2015.1049482 
Kilanski, K. R. (2015). A boom for whom? Gender, labor, and community in a modern day oil boomtown. (Unpublished doctoral dissertation). University of Texas at Austin.

Komarek, T. M. (2018). Crime and natural resource booms: Evidence from unconventional natural gas production. The Annals of Regional Science, 61(1), 113-137. https://doi.org/10.1007/s00168-018-0861-x

Lim, S. H. (2018). Does shale energy development mean more crime? The case of the Bakken oil boom. Growth and Change: A Journal of Urban and Regional Policy, 49(3), 413-441. https://doi.org/10.1111/grow.12242

Map Room. (2017). Industry and violence against Indigenous women. World Policy Journal, 34(4), 44-45. https://doi.org/10.1215/07402775-4373674

Martin, K., Barrick, K., Richardson, N. J., Liao, D., \& Heller, D. (2019). Violent victimization known to law enforcement in the Bakken oil-producing region of Montana and North Dakota, 2006-2012. National Crime Statistics Exchange. https://www.ncjrs.gov/App/Publications/abstract.aspx?ID=274844

Maryfield, B., Orchowsky, S., Pierotte, L., Myrent, M., FireMoon, P., Rink, E., \& Skewes, M. (2019). Measuring the criminal justice system impacts of the increased presence of methamphetamine in the Bakken oil formation. Justice Research and Statistics Association. https://www.ncjrs.gov/pdffiles1/nij/grants/253270.pdf

Mayer, A., \& Hazboun, S. O. (2019). Does fracking drive you to drink? Unconventional oil and gas production and alcohol consumption in U.S. counties. The Extractive Industries and Society, 6(3), 823-830. https://doi.org/10.1016/j.exis.2019.04.002

Moen, E. (1981). Women in energy boom towns. Psychology of Women Quarterly, 6(1), 99112. https://doi.org/10.1111/j.1471-6402.1981.tb01063.x

Montana All Threat Intelligence Center and North Dakota State and Local Intelligence Center. (2012). Impact of population growth on law enforcement in the Williston Basin. Author.

Montana Board of Crime Control. (2014). Crime in Montana 2013-2014 report. Author. http://mbcc.mt.gov/Portals/130/Data/CIM/CIM2013-14.pdf

Montana Board of Crime Control. (2019). Montana crime trend dashboard. http://mtibrsrp.mt.gov/public/View/RSReport.aspx?ReportId=76

Montana Department of Justice. (2019). Montana domestic violence fatality review commissions. Author.

Morgan, R. E., \& Oudekerk, B. A. (2019). Criminal victimization, 2018. Bureau of Justice Statistics. https://bjs.gov/content/pub/pdf/cv17.pdf 
Morrison, T. H., Wilson, C., \& Bell, M. (2012). The role of private corporations in regional planning and development: Opportunities and challenges for the governance of housing and land use. Journal of Rural Studies, 28(4), 478-489. https://doi.org/10.1016/j.jrurstud.2012.09.001

Mrozla, T., Dahle, T. O., Huynh, C., Robinson, C., Archbold, C. A., \& Marcel, A. (2018). Fear of crime in an oil boomtown in Western North Dakota. Journal of Crime and Justice. 41(4), 364-381. https://doi.org/10.1080/0735648X.2018.1429297

Murphy, T., Brannstrom, C., Fry, M., \& Ewers, M. (2018). Economic-development stakeholder perspectives on boomtown dynamics in the Eagle Ford shale, Texas. Geographical Review, 108(1), 24-44. https://doi.org/10.1111/gere.12226

Nichols, N., \& Soper, M. C. (2007). Methamphetamine \& the energy industry in western Colorado. (Unpublished Paper). Mesa State College.

North Dakota Court System. (2016). 2015 annual report. Bismarck, ND: Author. https://www.ndcourts.gov/Media/Default/Court\%20Administration/AnnualReport/2015annualreport.pdf

O’Connor, C. D. (2015). Insiders and outsiders: social change, deviant others, and sense of community in a boomtown. International Journal of Comparative and Applied Criminal Justice, 39(3), 219-238. https://doi.org/10.1080/01924036.2014.973049

O'Connor, C. D. (2017). Oil, crime, and disorder: A methodological examination of the oil boom's impact in North Dakota. Deviant Behavior, 38(4), 477-491. https://doi.org/10.1080/01639625.2016.1197025

O'Donoghue, A. J. (2016, March 2). The advocate: Oil bust fuels rise in domestic violence. Deseret News. https://www.deseretnews.com/article/865649081/The-advocate-Bustfuels-rise-in-domestic-violence.html

Paraskova, T. (2018, July 29). Coke, meth and booze: The flip side of the Permian oil boom. OilPrice.com. https://oilprice.com/Energy/Crude-Oil/Coke-Meth-And-Booze-The-FlipSide-Of-The-Permian-Oil-Boom.htm

Pazzani, L.M. (2007). The factors affecting sexual assaults committed by strangers and acquaintances. Violence against Women, 13(7), 717-749. https://doi.org/10.1177/1077801207302699

Perry, J. R. (2007). The effect of energy development on the courts. Wyoming Law Review, $7(2), 321-329$. 
Pippert, T., \& Zimmer Schneider, R. (2018). "Have you been to Walmart?" Gender and perceptions of safety in North Dakota boomtowns. Sociological Quarterly 59(2), 234249. https://doi.org/10.1080/00380253.2017.1413602

Police Executive Research Forum. (2013). Policing in the economic downturn: Striving for efficiency is the new normal. Author.

https://www.policeforum.org/assets/docs/Critical_Issues_Series/policing\%20and $\% 20$ the $\% 20$ economic $\% 20$ downturn $\% 20$ -

\%20striving\%20for\%20efficiency\%20is\%20the\%20new\%20normal\%202013.pdf

Power, M., \& Power, D. (2019). The social costs of mining on rural communities. Power Consulting International.

https://static1.squarespace.com/static/571f8d69d51cd4590b8328fa/t/5d6f36781f0e4c000 1145b5a/1567569534257/Power+Report.pdf

Reaves, B. A. (2017). Police response to domestic violence, 2006-2015. Bureau of Justice Statistics. https://www.bjs.gov/content/pub/pdf/prdv0615.pdf

Rendahl, K. (2015). Domestic violence in the North Dakota oil patch: Barriers to identifying and serving female victims. (Unpublished dissertation). Hamline University.

Rick, K., Marten, I., \& Von Lonski, U. (2017). Untapped reserves: Promoting gender balance in oil and gas. Report prepared by Boston Consulting Group for the World Petroleum Council. https://www.bcg.com/en-us/publications/2017/energy-environment-peopleorganization-untapped-reserves.aspx

Ruddell, R. (2011). Boomtown policing: Responding to the dark side of resource development. Policing, 5(4), 328-342. https://doi.org/10.1093/police/par034

Ruddell, R. (2017). Oil, gas, and crime: The dark side of the boomtown. Palgrave Macmillan. https://doi.org/10.1057/978-1-137-58714-5

Ruddell, R., \& Ortiz, N. R. (2015). Boomtown blues: Long-term community perceptions of crime and disorder. American Journal of Criminal Justice, 40(1), 129-146. https://doi.org/10.1007/s12103-014-9237-7

Ruddell, R., \& Ray, H. A. (2018). Profiling the life course of resource-based boomtowns: A key step in crime prevention. Journal of Community Safety and Well-Being, 3(2), 38-42. https://doi.org/10.35502/jcswb.78

Schneider, D., Harknett, K., \& McLanahan, S. (2016). Intimate partner violence in the great recession. Demography, 53(2), 471-505. https://doi.org/10.1007/s13524-016-0462-1

Sincovich, A., Gregory, T., Wilson, A., \& Brinkman, S. (2018). The social impacts of mining on local communities in Australia. Rural Society, 27(1), 18-34. https://doi.org/10.1080/10371656.2018.1443725 
Smith, A., Heyes, K., Fox, C., Harrison, J., Kiss, Z., \& Bradbury, A. (2018). The effectiveness of probation supervision towards reducing reoffending: A rapid evidence assessment. Probation Journal, 65(4), 407-428. https://doi.org/10.1177/0264550518796275

Smith, K. K., Haggerty, J. H., Kay, D. L., \& Coupal, R. (2019). Using shared services to mitigate boomtown impacts in the Bakken shale play: Resourcefulness or over-adaption? The Journal of Rural and Community Development, 14(2), 66-86.

Springer, P. (2018, Sept. 24). Bakken reserves hold 30 to 40 billion barrels of recoverable oil, industry executive says. Grand Forks Herald. https://www.grandforksherald.com/business/energy-and-mining/4503673-bakkenreserves-hold-30-40-billion-barrels-recoverable-oil

Stretesky, P. B., Long, M. A., McKie, R. E., \& Aryee, F. A. (2018). Does oil and gas development increase crime within UK local authorities? The Extractive Industries and Society, 5(3), 356-365. https://doi.org/10.1016/j.exis.2018.03.006

Strong, S. M., Rantala, R. R., \& Kyckelhahn, T. (2016). Census of problem-solving courts, 2012. Bureau of Justice Statistics. https://www.bjs.gov/content/pub/pdf/cpsc12.pdf

Thomas, M. O., Smith, S. M., \& Ortiz, N. R. (2016). The boom's echo: Learning how to mitigate boomtown effects. Internet Journal of Criminology Special Issue on Boomtowns, 125138.

Titterington, V. B. (2006). A retrospective investigation of gender inequality and female homicide victimization. Sociological Spectrum, 26(2), 205-231. https://doi.org/10.1080/02732170500463429

Urwin, J. (2016, April 26). Boomtown bust: How the sputtering oil and gas industry is destroying men. Vice. https://www.vice.com/en_ca/article/xdm48a/boomtown-bust-howthe-sputtering-oil-and-gas-industry-is-destroying-men

U.S. Census Bureau. (2018). 2017 American community survey, Table B02010. https://factfinder.census.gov/faces/nav/jsf/pages/index.xhtml

U.S. Energy Information Administration. (2020). North Dakota field production of crude oil. https://www.eia.gov/dnav/pet/hist/LeafHandler.ashx?n=pet\&s=mcrfpnd2\&f=a

U.S. Food and Drug Administration. (2017). Drugs of abuse home use test. https://www.fda.gov/medical-devices/drugs-abuse-tests/drugs-abuse-home-use-test

Weber, B. A., Geigle, J., \& Barkdull, C. (2014). Rural North Dakota's oil boom and its impact on social services. Social Work, 59(1), 62-72. https://doi.org/10.1093/sw/swt068 